\title{
Knowledge networks and inter-organisational learning in the context of information industry
} Issues for quality management

Mikko J. Ruohonen and Tarja Tiainen

University of Tampere, Finland

\begin{abstract}
Organisations in the information industry are facing constant changes which demand organisational learning. Industry structures are being reformatted, which implies new processes and knowledge bases. Hence, interorganisational competitive advantage also needs cross-organisational learning, learning support systems and management approaches considering quality in this change context. Critical qualities for inter-organisational advantage will be reviewed, likewise the nature of knowledge work for improved quality management.
\end{abstract}

Key words: knowledge work, information industry, inter-organisational learning, quality management approaches

\section{TRANSFORMATION OF INFORMATION INDUSTRIES}

Information and communications technology (ICT) is no longer only a tool to improve cost-effectiveness; it also has great potential for innovation (Rogers, 1983). Electronic business and learning are claimed to start the change of operations models, organisational processes, ways to meet and serve the customer and share knowledge within the industrial context (Kalakota \& Robinson, 2001). Functional hierarchies turn out to be more organised networked structures. The new business potential is increasingly found on the international market and so different collaboration and outsourcing strategies will become more important (Shepherd, 1999; Stabell

The original version of this chapter was revised: The copyright line was incorrect. This has been corrected. The Erratum to this chapter is available at DOI: 10.1007/978-0-387-35700-3_33 
\& Fjeldstad, 1998). However, collaboration is not based solely on transferring transactions between companies. It also entails sharing knowledge, uniting and integrating processes and developing joint measures for operations. We call this phenomenon the era of knowledge management networks (Ruohonen \& Salmela, 1997).

Different ICT-based products and services provide opportunities for innovations. However, seizing opportunities needs a strong commitment and the ability to network. The management of co-operation between the organisations is a challenge. Formal agreements and contracts between organisations are just a beginning - the building of knowledge networks demands new qualities both in organisations and their managers (Stabell \& Fjelstad, 1998; Kasvio et al, 2000). In this paper, we focus on the learning challenge entailed in creating in knowledge networks. Besides addressing learning, we describe its context - networks and the information industry.

\section{MANAGEMENT OF INTERORGANISATIONAL COMPETITIVE ADVANTAGE}

The following four qualities (Dyer \& Singh, 1998) are important as the source of competitive advantage between organisations. They are 1) relation-specific assets i.e. investing in the specific relationship of partners; 2) knowledge-sharing routines and processes between partners; 3) complementary resources supplementing this core competencies of each partner; and 4) effective governance of the collaboration relationship. The knowledge creating companies should manage all of these qualities. For example, when the company either co-operates within an ICT project or has an outsourcing service relationship with the customer company, knowledge creation is necessary. This is reflected in the building and maintenance of electronic marketplaces, in the administration of communication network services or in the management of intranets and elsewhere.

- Relation-specific assets

The co-operation relationship between organisations is not merely the control of formal agreements; the organisations must commit themselves to long-term co-operation. Service outsourcing begins the co-operative relationship with many options. Pricing, cost control and exit provisions only provide a skeleton for a tighter co-operation relationship. It must be possible to evaluate the outsourcing operations and at the same time to make selective outsourcing possible. The outsourcing which produces added value leads to the changing of co-operation models and the mere cutting of costs remains 'business-as-usual' (Lacity \& Hirscheim, 1993). 
The service provider organisation must be able to learn the business model of the customer organisation. At the same time the customer organisation has to be ready to become acquainted with the service alternatives beyond the approach of transaction costs. The professionals' work in the service organisation must be in line with customer responses. One must commit oneself to continuous investment in that relationship, both economic and mental. The success of the co-operation is strengthened especially by mutual trust, which is claimed to be a necessary condition for a genuine co-operation project.

- Knowledge-sharing routines between partners

Currently many branches organise their information services behind common web-based business portals. This takes place in the frequent flyer services (e.g. www.oneworld.com), the tourism service (e.g. virtual.finland.fi), procurement of the car industry (e.g. www.covisint.com), and so forth. Unfortunately business portals are too often only cybercrossings or hyperlink lists.

Knowledge exchange is needed when stakeholders learn from each other for improved service and better competitiveness. If the portal holder considers the meeting place only as a means of strengthening its own position on the market, the portal becomes rather the bulletin board which is full of advertisements. However, if the portal is created for problem-solving it requires a common knowledge sharing practice between the portal partners and customers. The transfer of customer knowledge is difficult because the knowledge is context related. Many organisations have developed their services continuously for a long time towards being proactive, with the right pricing of services and anticipation of customers (El Sawey et al, 1999). The added value is thus not based on control of the transaction costs, it is sought beyond the control of the traditional value chain (Stabell \& Fjelstad, 1998).

\section{- Complementary resources or capabilities}

The resource-based theory from the firm (RBTF) (Barney, 1991) calls for those resources which are valuable, rare, difficult to copy and effectively organised. The core competence (Prahalad \& Hamel, 1990) has often been created over time, self-steered and even by chance. It is difficult for management particularly to see the importance of competences created at the floor level. The learning created in interaction with customers provides a foundation for that success. However, these competences may become obsolete if competitive or technological changes affect our business environment.

The competitive advantage of knowledge networks is created through the clustering process in which two or more organisations with complementary competencies begin to compete against other competitors' clusters having similar interests. The complementary competences can open up new markets 
and technology areas. Traditionally such situations are avoided in which espionage or theft of corporate core competences is obvious. On the other hand, external competences should be produced in the hyper-competitive businesses (D'Aveni, 1995; Matusik \& Hill, 1998).

- Effective governance of the relationship

Competitive advantage is not achieved if the costs of the cooperation exceed the level of other competitors. Thus the project, such as the service portal, must be governed effectively, both the technical infrastructure and the contents i.e. services. The co-operation rules must be created while different stakeholder groups control their own interests. A mediating organisation may be useful as an official broker functioning either formally or based on partner relationships. Both modes of action dedicated to some individuals and the processes must be clear and explicit to every partner. The broker must be able to operate fast without the constant arrangement of meetings when the cooperation and customer interface changes. Situations in which this customer setting has to be evaluated and checked will be continuously created.

\section{KNOWLEDGE WORK IN INFORMATION INDUSTRIES}

Organisational work is still more fragmented and uncommitted to place and time. At the same time the traditional barriers between the worker and manager have broken down and in the future more knowledge workers will be needed. The management of this kind of work requires quite a different approach compared to traditional industrial work. The productivity of knowledge work is the keyword for change. The factors which determine knowledge work productivity are 1) characteristics of the work assignment, 2) autonomy of the knowledge worker, 3) constant innovativeness, 4) constant learning and teaching, 5) balance of volume and quality and 6) the knowledge worker's commitment to the organisation (Drucker, 1999).

- Constant internal change of the tasks and routines of knowledge work

In knowledge work changes which emphasise the control of different targets of application generators and technology platforms take place continuously. The focus in building homepages has moved to larger applications in which an old homepage becomes an interactive customer service portal. This requires new competences concerning the management of a larger amount of customer visits and the integration of databases. Partners to the outsourcing or application provision relationship should be able to follow this evolution continuously. 
The administration and management support tasks (meetings, reporting, e.g.) are a common source of non-productivity. Because of the general responsibility to inform etc., knowledge work is interrupted and delayed several times per day. An attempt must be made to reduce the share of these tasks and to outsource most of them, because the knowledge worker must be able to concentrate on his/her actual work (such as on the definition of the new product). Typically small IT organisations are growing in size and business volume, most of the administrative procedures are neglected. Later on this affects productivity and causes quality problems. Managers need to be aware of this shift when business is growing.

- The worker's autonomy and responsibility

The knowledge worker must take responsibility for his/her own work and its development. When many branches of business grow aggressively, this can lead to withdrawal and isolation, in other words each worker only takes care of his/her own 'business'. For example, in the multimedia software house, the artist produces the best possible graphic design, the programmer takes care of the application and the project manager worries about customer needs. These interests may also be in conflict either among themselves or the advantages of the customer. The knowledge worker must therefore also take responsibility for success and quality from customer's point of view. These viewpoints should be explicated in the project roles and meetings. However, this does not mean that the success of the project must be made more complicated with too many different checks and with formal management systems. The supervision of the project can also be carried out by individual self-control or by 'clan-control' i.e. control by team members (Kirsch, 1997).

\section{- Innovations and creativity}

Knowledge workers must be able to incorporate different innovation methods into their own work. Many innovations are a result of an incremental and constant innovation process. Many of today's innovations are endangered simply as a consequence of neglecting the customer's perspective. Innovation diffusion is one of the promising theories for observing customer views when adopting new ideas, products or processes. Innovation should be easily understood and can be adopted with minor changes to work or other activity (Rogers, 1983). Creating knowledge work innovations presupposes a working environment which supports innovativeness..

\section{- Methods of constant learning and teaching}

The methods of incidental and workplace learning in particular provide a significant form of learning. In IT-intensive knowledge work application generators and technology platforms change at such a speed that the formal 
training systems do not necessarily have time to react. The learning in workplaces requires reflectivity and setting up of reflective processes (Jårvinen \& Poikela, 2001). Superiors and managers should support professionals' reflection. At the same time personnel are trained to teach of each other. Peer-to-peer training competences are currently part of the job description. We must also note that many of the systems which do support learning are embedded in the work processes. It is important to integrate elearning and e-work. Many of the vendors are developing products for both purposes. It seems that effective management of the learning organisation combines these two major challenges.

\section{- Balance of volume and quality}

The balance of volume and quality is found when the costs and time limits of projects are compared. Quality can be defined in many ways. Reeves and Bednar (1994) have found the following definitions of quality in their own historical overview. Quality is: 1) excellence, 2) value, 3) conformance to specifications, and 4) meeting or exceeding customers' demands. If quality is considered as an excellence it could mean a worldclass product or service. Quality would normally mean success in export markets and in an otherwise unique product or service. In certain areas the ICT companies have been able to achieve this quality.

If quality is considered as a value it may mean that when markets differentiate, the companies have quality as a kind of a final state ('you cannot get a better one'). The quality of some products and services is related to a buying event, such as a convenience or availability (Cronin \& Taylor, 1992). In the information industry different choices have been made regarding in what kind of operating situations the product is needed and what it costs. For example, the satellite phone system was first considered as the actual final state of quality, but only a few people were ready to pay for this quality. It must be possible to evaluate the quality of the different network services and the customers' desire to pay for them in the same way.

The quality can be evaluated at different stages of the process, such as the quality of planning and implementation. With the help of industrial quality standards production, processes have been improved by many statistical methods. This has achieved good outcomes with processes and prevented the occurrence of mistakes. The role of specifications is most important here because without these it is not possible to control the quality of the implementation. In knowledge work looseness of specifications can turn into a problem.

Furthermore, quality is connected to the satisfaction of customers' needs. This view of quality does not fit well with knowledge work, since the customer cannot necessarily articulate his/her needs in consultation and teaching situation. The customer must therefore be led to the core of the problem before being offered the solution. It is ethically questionable but 
nevertheless very common to offer and sell the customer a beta solution and then try to take on new deals after the customer has learnt what he/she needs. In the growing fields of the information industry this kind of quality easily leads customers astray.

The constant evaluation of quality of service and organisational measurement of individual customer satisfaction may produce more problems. The product (e.g. a network service) that earlier achieved high quality may quickly become obsolete in the customer's mind if competitors produce relatively more effective or modern alternatives.

\section{- Commitment to the organisation}

Knowledge workers are usually growth-oriented and professionally qualified people with little interest in traditional ways of working. They are also constantly seeking new opportunities to learn. The demands for learning technology and up-to-date processes are clear. Organisations which can serve a flexible learning environment which is both efficient and customised for each knowledge worker's needs are usually in a more competitive position when recruiting new employees. The learning culture encourages people to commit to the organisation.

\section{FINAL REMARKS}

A theoretical grounding for improved quality management in interorganisational learning and knowledge work was reviewed. Competition and increasing pressure to make a networked economy demands new competencies. Inter-organisational competitive advantage requires crossorganisational processes. Knowledge work has to face productivity objectives. Managers need to identify the context in which they are working in order to align with the variety of their personnel.

\section{REFERENCES}

Barney, J.B. (1991) Firm resources and sustained competitive advantage. Journal of Management 17(1): 99-120.

Cronin, J.J. Jr \& Taylor, S.A. (1992): Measuring service quality: A reexamination and extension. Journal of Marketing 56(3): 55-68.

D'Aveni, R. A. (1995): Hypercompetition: Managing the dynamics of strategic maneuvering. New York: Free Press

Drucker, P.F. (1999): Knowledge-Worker Productivity - The Biggest Challenge. California Management Review 41(2): 79-94

Dyer, J.H. \& Singh, H. (1998): The relational view: Cooperative strategy and sources of interorganisational competitive advantage. Academy of Management Review 23(4): 660679. 
El Sawy, O.A., Malhotra, A., Gosan, S. \& Young K.M. (1999): IT-Intensive Value Innovation in the Electronic Economy: IT-Intensive Value Innovation in the Electronic Economy: First Prize, 1997 SIM International Paper Awards Competition.

Järvinen, A. \& Poikela, E. (2001): Modelling reflective and contextual learning at work. Journal of Workplace Learning; 13(7/8): 282-289.

Kalakota, R. \& Robinson, M. (2001): E-Business 2.0. Addison Wesley Longman, Reading, Massachusetts..

Kasvio, A., Haapakorpi, A., \& Ruohonen, M. (2000): Joustavat työjärjestelyt. Esitutkimusraportti. Tampereen yliopiston tietoyhteiskunnan tutkimuskeskuksen työraportteja 12/2000. Tampere: TAY.

Kirsch, L. (1997): Portfolios of control modes and IS project management. Information Systems Research; 8(3): 215-239.

Lacity, M.C. \& Hirscheim, R. (1993): Information systems outsourcing myths, metaphors and realities. Wiley, Chichester.

Matusik, S.F., Hill, C.W.L. (1998): The Utilization of Contingent Work, Knowledge Creation, and Competitive Advantage. Academy of Management Review 23(4), 680-697.

McFarlan, F.W. \& Nolan, R.L. (1995): How to Manage an IT Outsourcing Alliance. Sloan Management Review 36(2): 9-23.

Prahalad, C.K. \& Hamel, G. (1990): The core competence of the corporation. Harvard Business Review 68(2): 79-91.

Reeves, C.A. \& Bednar, D.A. (1994): Defining quality: Alternatives and implications. Academy of Management Review 19(3): 419-445.

Rogers, E. (1983): Diffusion of Innovations. New York: Free Press

Ruohonen, M. \& Salmela, H. (1999): Yrityksen tietohallinto. Edita, Helsinki.

Saunders, C., Gebelt, M. \& Hu, Q. (1997): Achieving success in information systems outsourcing. California Management Review 39: 63-79.

Shepherd, A. (1999): Outsourcing IT in a changing world. European Management Journal 17(1): 64-84.

Stabell, C.B. \& Fjeldstad, Ö,D. (1998): Configuring value for competitive advantage. on chains, shops, and networks. Strategic Management Journal 19: 413-437.

Turban, E., King, D., Lee, J., Warkentin, M. \& Chung, H. (2002): Electronic Commerce - a Managerial Perspective. Prentice Hall. 